\title{
THE EFFECT OF TEAM WORK, LEADERSHIP STYLE, AND ORGANIZATIONAL CULTURE ON NURSE PERFORMANCE WITH ORGANIZATIONAL COMMITMENTS AS MEDIATION VARIABLES IN HOSPITAL TYPE B IN JAKARTA
}

\author{
Sri Ari Wahyuningsih ${ }^{1}$, Armanu Thoyib ${ }^{2}$, Rofiaty $^{3}$, Ananda Sabil $^{4}$ \\ 1,2,3,4 College of Management, University of Brawijaya, Indonesia
}

\begin{abstract}
This study aims to analyze the influence of team work, leadership style and organizational culture on nurse performance with organizational commitment as a mediating variable. The research unit is nurses at Type B hospitals in Jakarta. The population is 1362 nurses. Methods of collecting data using surveys. The research instrument used a questionnaire. Questionnaires were distributed to 523 respondents. Data analysis method uses Structural Equation Modeling-Partial Least Square SEM-PLS). The results of the study prove that teamwork has a positive effect on nurse performance. Teamwork does not affect organizational commitment. Organizational culture has a positive effect on nurse performance. Organizational culture has a positive effect on organizational commitment. Leadership style does not affect nurse performance. Leadership style does not affect organizational commitment. Organizational commitment has a positive effect on nurse performance. Organizational commitment cannot play a role in mediating the influence of teamwork on nurse performance. Organizational commitment can play a role in mediating the influence of organizational culture on nurse performance. Organizational commitment cannot play a role in mediating the influence of leadership style on nurse performance.
\end{abstract}

Keywords: Teamwork, Organizational Culture, Leadership Style, Organizational Commitment, Nurse Performance. 


\section{INTRODUCTION}

In the past a hospital management was a public service, but along with the increasing public awareness of health, of course more and more people were treated, thus causing the health services provided by hospitals to decline. This usually happens in government hospitals, because public services are social, but private hospitals are profit oriented, so the cost of treatment is very high. The high cost of treatment, medical personnel services that are not in accordance with the requests of patients at this private hospital, cause the hospital connoted to provide less good service. Patient safety in the health care system has long been a concern, but despite positive changes in practice, health systems and regulations, the desired level of patient safety remains unattainable. The competence of health nurse leaders to make positive changes to the work environment, as well as the management of nursing staff is important for the success of teams and organizations in hospitals. Improving the quality of health services can encourage competition between hospitals, both government and private sector, which are increasingly tighter in seizing an increasingly open market.

At this time friendliness, perseverance, patience and accuracy in giving medicine, right people, right dosage and on time, are excellent services that must be given by the hospital. This can be indicated by the nurse's behavior which is an extension of the doctor's hand in serving patients, it is not uncommon for the nurse's empathy to play a role in the patient's recovery process. The health care system is considered to be one of the most complex and interrelated components (Glouberman and Mintzberg, 2001; Reay. et al., 2016), primarily managing health service activities and planning for change.

Andersson (2015) and Kannampall. et al., (2011) have shown the complexity of health care and its effect on the quality of patient care and the independence of hospital employees to make changes to the organization. In private hospitals in major cities in Indonesia, there is a very tight competition, this is a threat to government hospitals. The service includes both doctors, medical teams and other facilities, so it is a challenge for hospitals to improve services and overall performance. This requires hospital management to manage its business professionally, in the sense that it can satisfy and fulfill the objectives of the stakeholders.

Vol. 27, No. 3 December 2019

(C) Centre for Indonesian Accounting and Management Research Postgraduate Program, Brawijaya University 
The success of the hospital, not only on the completeness of the superior facilities, but also the attitudes and services of human resources to patients. If the element is ignored, the hospital will lose a lot of patients, the community will leave the hospital and switch to another hospital that is in line with the patient's expectations.

Nurses in work often face many problems, but nurses remain strong and accept every problem they face, although often they find it difficult to work in a non-respectful environment and lack cooperation in the team. This team collaboration can be built when fellow co-workers give mutual respect and do work together in a job. Tracy (2006) states that teamwork is an activity that is managed and carried out by a group of people who are members of one organization. Usually teamwork consists of people who have different skills so that they become strengths in achieving company goals. Change is a certainty that demands improvement in all fields in a sustainable manner, certainly not free from the power of the leadership of the organization. Hospital leaders, employees and patients and visitors are interconnected in creating a safe, comfortable, peaceful atmosphere so that the patient's healing process can be accelerated. Leadership style has also been found as an important predictor of organizational performance (Bass. et al., 2003). Nurses are often targeted by patients in overcoming dissatisfaction with hospital services, but nurses in charge always have commitment, no matter how heavy the demands of patients are still faced and remain faithful to assist patients in the healing process.

Commitment has an impact on some work-related attributes, such as the intention to stay (Chew and Chan, 2008; Meyer. et al., 2002), better attendance (Meyer. et al., 2002). In addition, committed employees are more likely to have high work motivation., as well as better work performance (Abdul Rashid et al, 2003; Chen et al. 2006; Riketta, 2002; Samad, 2005; Yousef, 2000). Yeh (2014) emphasizes that organizational commitment has three types, namely affective (identification), continuity (involvement) and normative (loyalty). Affective is focused on emotional feelings and employee attachments to the organization. Normative commitment to the organization is determined by the feelings and obligations of the nurse towards the organization and the intention to leave the organization. At present the management of the hospital is done 
very seriously in solving various situations. Al-Hussami. et al., (2018) provides advice to policy makers and health care leaders to make management changes and conduct leadership training and make efforts to change nationally. Social implications are very important to see the extent to which health professionals, especially nurses, understand the influence of organizational support and organizational commitment on organizational readiness to make changes.

Lee and Cummings (2008) argued that the workload of nurses was too large to influence work effectiveness. The workload must be overcome to optimize its function because the nurse leader directly or indirectly influences the performance of subordinates, so that the goals of the health organization can be realized. This is of course supported by the relationship between nurses, doctors and other medical personnel, and leaders who can show the performance of a hospital. In investigating problems and variables that affect the performance of nurses in a hospital, a scientific approach is used in order to find interrelationships between variables so that the performance of nurses in hospitals can be measured.

The phenomenon of hospitals in Indonesia is not a comfortable place to seek healing. Patients can inhabit a treatment room, the patient's family must issue a deposit as a deposit, without paying a minimum down payment, the patient cannot get the proper care. It is not uncommon for patients to get worse because they are not quickly handled, that is a bit of a blurred portrait of poor health services in our country (Cahyadi, 2010). Many patients do not get care and rooms, this is because the hospital rejects the patient on the grounds that the room is full or there are no tools needed by the patient. No wonder people who have excess money choose to fly abroad, Singapore or Malaysia. This is where heaven gets health services that are in accordance with patient expectations. The lack of human health services at the hospital, making Indonesian people seek healing abroad, approximately $50 \%$ of patients outside Singapore are Indonesian citizens. Outside health services, including Singapore, are very friendly and easy (Cahyadi, 2010). Friendliness created makes patients feel comfortable and sure to recover. 
Empaty nurses and other medical personnel make patients motivated to be healthy .

On the other hand altruism nurses can foster the trust of patients and their families to get enormous attention in care, at least patients feel healing is in the intervention of nurses and other medical teams. The existence of specialists has a big contribution in the process of quality service in hospitals, should be able to improve services, in fact specialists are not fully devoted to themselves, so nursing duties are often borne by existing nurses. Jalal Hanaysha (2016), founded that teamwork effects on positive and significant organizational commitment. This is due to the fact that employees with a high level of commitment to the organization are usually more productive, harmonious, and have better loyalty to the organization. In industrial companies, the commitment of employees in the industry is strongly influenced by salary, nature of work, corporate culture, direct managerial behavior, and corporate leadership. Organizational commitment is generally beneficial for both parties because it can strengthen ownership, job security, career development, increased compensation. Diab and Ajlouni (2015) suggested that indicators of employee commitment are loyalty, responsibility, willingness to continue work, and trust in the organization.

Organizational culture can increase employee commitment to the norms and values they receive. The organizational \& cultural environment that applies to the company influences employee commitment. In some previous studies organizational culture variables did not use altruistics as an indicator, but in this study researchers included in the indicator, because this research was conducted on hospital nurses. Likewise, performance variables in previous studies, researchers have not found that empathy as an indicator, four nurses can accelerate the recovery of patients, where the relationship between nurses and patients is very close, in this study the researchers included it as an indicator.

A leader plays an important role in maintaining medical and nonmedical staff, to be able to survive in an organization by understanding the goals of an organization, so it can influence the development of organizational performance. This description reflects that the condition of Vol. 27, No. 3 December 2019

(C) Centre for Indonesian Accounting and Management Research Postgraduate Program, Brawijaya University 
hospitals in Indonesia is still far from what is expected, so this phenomenon is the basis of research whether nurse performance is low due to inappropriate teamwork, work culture, or inappropriate leadership style in hospitals, so that it will influence commitment nurse and performance.

The tight competition in the field of health services requires hospitals to recruit health professionals who are professional, in order to gain public sympathy, this encourages leaders to change the mindset of employees related to their duties (Robbins, 2012). Nurses are the foundation of all existing activities and one source of success or failure of health services in hospitals. The effective performance of the nurse team will bear fruit in achieving maximum service quality.

Hospitals with global competitiveness realize that in order to survive amid the high level of competition, they must pay attention to the global environment, one of which is to improve the quality and experience of their HR. For the leaders of hospitals operating internationally, the challenges of globalization faced are certainly very large. This quality requires hospitals to improve their human resources and health facilities in supporting patient health.

This research fills the research gap with organizational commitment variables mediating the influence of teamwork, organizational culture and leadership style on nurse performance. Because in general, research is done using other variables such as innovation, job satisfaction, commitment and others. Teamwork variables influence the commitment of nurses is still limited, thus inspiring researchers to add teamwork variables in nursing patients in hospitals. Empathy nurses are expected to have the ability to carry out communication actions consciously to patients so they can understand and feel the patient's feelings. Building teamwork between employees, doctors and other medical personnel is very necessary, so that this condition can encourage better performance. Teamwork variables influence on organizational commitment is still limited, so it inspires researchers to study teamwork in nursing patients in hospitals. 
In recent years, leadership style has become important in the field of management, and many researchers consider leadership style as an important variable in influencing how members of the organization function (Wu, 2009). Changes in an organization are strongly influenced by the behavior of leaders in an organization, such as organizational commitment, organizational support. The performance of nurses in hospitals will not work well if leadership does not show a reflection of leadership and will have an impact on nurses' performance which is declining.

Organizational culture can increase employee commitment to the norms and values they receive. The organizational \& cultural environment that applies to the company influences employee commitment. In some previous studies organizational culture variables did not use altruistics as an indicator, but in this study researchers included in the indicator, because this research was conducted on hospital nurses. Likewise, performance variables in previous studies, researchers have not found that empathy as an indicator, in this study researchers included it as an indicator.

Commitment has an impact on some work-related attributes, such as the intention to stay (Chew and Chan, 2008; Meyer. et al., 2002), better attendance (Meyer. et a.l, 2002). In addition, committed employees are more likely to have better work performance (Abdul Rashid. et al., 2003; Chen. et al., 2006; Riketta, 2002; Samad, 2005; Yousef, 2000). The relationship between leadership style, organizational commitment and organizational performance was also examined by Zehira. et al., (2012). The research findings are that organizational commitment does not affect organizational performance, but leadership style influences performance and commitment directly. This research fills the research gap with organizational commitment variables mediating the influence of teamwork, organizational culture and leadership style on nurse performance. Based on the description above, this research was conducted to explore "The Effect of Team Work, Leadership Style and Organizational Culture on Nurse Performance with Organizational Commitment as a Variable Mediation in Type B Private Hospitals in Jakarta”. 


\section{STUDY OF LITERATURE}

\section{Team Work}

Teamwork is a group of people who work together to achieve the desired goals (Ooko, 2013), while Tracy (2006) argues that teamwork is an activity carried out by a group of people in an organization, so that it can improve cooperation and communication between parts of an organization. Teamwork is the mental and emotional preoccupation of individuals in group situations that motivate them, in order to work together to achieve group goals and participate in accountable for a job. Teamwork in hospitals and health institutions in general can affect staff effectiveness, so that it can improve nurse performance and ultimately improve patient safety (Brandrud. et al., 2011), (Paine. et al., (2010), (Thomas , 2011) Gallie. et al., (2009) revealed that teamwork increases employee productivity and leads to a better level of organizational commitment.Through teamwork, each employee will have the opportunity to share experiences, knowledge and learning from others, this can result in increase commitment and productivity as well as overall team performance From the several opinions, the research hypothesis that can be built is:

H1: Teamwork has a positive effect on nurse performance.

$\mathrm{H} 2$ : Teamwork has a positive effect on organizational commitment

Vol. 27, No. 3 December 2019

(C) Centre for Indonesian Accounting and Management Research Postgraduate Program, Brawijaya University 


\section{Organizational Culture}

Schein (2004) defines organizational culture as a pattern of shared basic assumptions learned by a group such as solving external and internal problems, as a correct way to understand, think, and feel there is a connection with the problem. As for Robins (2006), defining organizational culture is a system adopted by members of the organization so that it can show differences with other organizations. Organizational culture can increase employee commitment in an organization with norms and values that can be accepted by them (Rahmani. et al., 2015). Organizational culture can play an important role in creating understanding and a favorable work environment so that employees can commit to making a positive contribution to the welfare of the organization. Conformity between organizational culture towards participation that supports it will lead to job satisfaction that encourages individuals to be creative in the sense that it can improve company performance. From some of these criteria, the hypotheses 3 and 4 that are built next

are:

H3: Organizational culture has a positive effect on nurse performance.

H4: Organizational culture has a positive effect on organizational commitment.

\section{Leadership Style}

Robbin (2006), states that leadership can be interpreted as an ability to influence groups in achieving goals. This opinion is in line (Yukl, 2007), that leadership is a process of influencing other people to understand and approve tasks that must be carried out effectively, as well as a process in the efforts of individuals and groups in achieving goals together. Jackson. et al., (2010), argues that effective leadership is leadership that ensures employees work to achieve results that are consistent with their vision, mission and values. Without strategic and effective leadership, it is difficult for organizational members to maintain profitability, productivity, and competitive advantage (Lussier and Achua, 2007). De Groot. et al., (2000); Hardini (2001); and Silverthone \& Wang (2001); found that leadership style had a positive effect on employee performance. However, there are still several studies that find Vol. 27, No. 3 December 2019

(C) Centre for Indonesian Accounting and Management Research Postgraduate Program, Brawijaya University 
that leadership styles negatively affect employee performance. From the results of the above studies, the next hypothesis is: H5: Leadership style has a positive effect on nurse performance

H6: Leadership style has a positive effect on organizational commitment

\section{Organizational Commitment}

Robbins and Judge (2015) said that commitment is a situation where someone who sided with the organization in accordance with the goals and desire to maintain membership in the organization. Commitments in hospitals are of course also required to be able to uphold mutually agreed values in hospitals, especially nursing staff. Nurse commitment is seen as important in the hospital, which relies on values of commitment, dedication, loyalty, high competence and a strong desire to realize nurse performance. Ivancevich, Konopaske, and Matteson (2006) define organizational commitment as identification, involvement, and loyalty expressed by employees towards an organization or company. Robbins (2007) argues that organizational commitment is a commitment created by all individual components in carrying out the organization's operations. Based on the research of Khan. et al., (2012), and Fang. et al., (2014) that organizational commitment has a positive effect on organizational performance. Luthans (2006) conducted a study in which the results of the study showed that organizational commitment played a role in performance, so the 7th hypothesis could be stated as follows:

H7: Organizational commitment has a positive effect on nurse performance.

Shein and Einar, 2005; Parry and Thomson, 2003, prove that organizational culture has a positive effect on employee performance. Research conducted by Chen (2004) shows that organizational culture has a significant positive effect on organizational commitment and employee performance. The 8th hypothesis can be formulated:

H8: Organizational commitment is able to play a role in mediating the influence of teamwork on nurse performance.

H9: Organizational commitment is able to play a role in mediating cultural

influences

organization of nurse performance

Vol. 27, No. 3 December 2019

(C) Centre for Indonesian Accounting and Management Research Postgraduate Program, Brawijaya University 
Walumbwa, et al., (2005); Avolio. et al., (2004) conducted that a study of nurses in hospitals in Singapore, finding about leadership styles had a positive effect on organizational commitment. If the leadership style of a leader can convince his subordinates, then his subordinates will be willing to follow the company's goals to be achieved, so that it will have an impact on organizational commitment. As for development research conducted by Darwito (2008), shows that leadership styles can directly influence performance, but can also indirectly influence employee performance through organizational commitment.

\section{Performance Of Nurses}

Information on the performance of an organization can be used as planning material, determine the level of success of the organization to decide on an action, and others. According to Mangkunegara (2002), to measure performance variables, four dimensions are used, such as each regarding work quality, work quantity, efficiency, employee ability, timeliness, employee knowledge and creativity. Organizational commitment can act as a mediator (Yueh, 2004), commitment as a mediator in the relationship between leadership and Chen's company performance. et al., (2009). The relationship between leadership style variables, organizational commitment and organizational performance was also examined by Zehira. et al., (2012), who found that organizational commitment was able to play a role in mediating the influence of leadership on employee performance, so the 10th hypothesis could be built as follows: H10: Organizational commitment is able to play a role in mediating the influence of style leadership on nurse performance.

\section{RESEARCH METHODS}

\section{Population and Samples}

The population in this study were nurses who were present at Type B private hospitals in Jakarta. The elements in question are each nurse member who has worked at least 2 years in a type B private raft in Jakarta, totaling 1362 nurses. Ferdinand (2013), states that (a) sample size is recommended for multivariate analysis in the range of 100 to 200; The analysis used by SEM is equal to 5 to 10 times the number of 
coefficients or parameters in the model. The calculation is 33 indicators, 7 lines with 2 endogenous variables. It means that from 33 indicators there are 33 error values from the factor loading value on each indicator to latent constructs, 7 paths, and errors in endogenous variables, so the number of parameters or coefficients becomes 75. Based on the criteria of 5 to 10 times the number of coefficients, the sample size is between 375 to 750 . In this study the number of samples collected was 523 respondents. The sampling method uses proportional random sampling, which is by taking samples at each hospital determined to be balanced or proportional to the number of objects in each hospital, which is done randomly (Arikunto, 2006). Previous research found that some newly graduated nurses left the nursing workforce after one to two years of practice, this was due to nurses working conflicts with the reality of very heavy nursing workloads (Duffield et al., 2008; Leiter, Jackson and Shaughnessy, 2009; Takase et al., 2006).

\section{Data Analysis Methods}

\section{Analysis of Descriptive Statistics}

This analysis aims to describe the demographic characteristics of respondents, namely the age of the respondent, the education of the respondent, length of work, salary and others. Describing the respondent's answer to the instrument relates to the indicator of the research variable, the respondent's answer uses the Likert scale 1-5.

2. Analysis of the Structural Equation Model - Partial Lest Square

The analysis of this study used Component or Variance Based Structural Equation Modeling or Structural Equation Model - partial least square, or Partial Least Square, where the data processing uses the Partial Least Square (PLS) program. PLS besides being used as confirmation theory can also be used to build relationships or to test propositions (Ghozali, 2014). PLS can also be used to explain the presence or absence of relationships between latent variables.

\section{RESULTS AND DISCUSSION}

\section{Hypothesis Testing Results}

The estimated value for track relationships in the structural model must be significant. This significance value can be obtained by bootstrapping procedure. If the value of $t$ statistic $>t$ table then the hypothesis is accepted with $\alpha=5 \%$.

Vol. 27, No. 3 December 2019

(C) Centre for Indonesian Accounting and Management Research Postgraduate Program, Brawijaya University 


\section{Table 2. Hypothesis Testing Results The Role of Organizational Commitment as a Mediation variable}

\begin{tabular}{|c|c|c|c|c|c|}
\hline Relationship between variables & $\begin{array}{l}\text { Original } \\
\text { Sample }\end{array}$ & $\begin{array}{l}\text { Standard } \\
\text { Deviation }\end{array}$ & $\begin{array}{l}\text { Standard } \\
\text { Error }\end{array}$ & $\stackrel{\mathbf{t}}{\text { Statistics }}$ & Results \\
\hline Teamwork $\rightarrow$ Nurse Performance & 0.256897 & 0.119946 & 0.119946 & 2.141772 & Accepted \\
\hline $\begin{array}{l}\text { Teamwork } \\
\text { commitment }\end{array} \rightarrow$ Organizational & 0.135163 & 0.119614 & 0.119614 & 1.129996 & Rejected \\
\hline $\begin{array}{l}\text { Organizational Culture } \rightarrow \text { Nurse } \\
\text { Performance }\end{array}$ & 0.259294 & 0.115024 & 0.115024 & 2.254258 & Accepted \\
\hline $\begin{array}{l}\text { Organizational } \\
\text { Organizational commitment }\end{array} \quad \rightarrow$ & 0.533246 & 0.108131 & 0.108131 & 4.931489 & Accepted \\
\hline $\begin{array}{l}\text { Leadership } \\
\text { Performance }\end{array}$ Style $\rightarrow$ Nurse & 0.006336 & 0.070536 & 0.070536 & 0.089827 & Rejected \\
\hline $\begin{array}{l}\text { Leadership } \quad \text { Style } \\
\text { Organizational commitment }\end{array}$ & 0.080662 & 0.089908 & 0.089908 & 0.897155 & Rejected \\
\hline $\begin{array}{l}\text { Organizational commitment } \\
\rightarrow \text { Nurse performance }\end{array}$ & 0.396587 & 0.124024 & 0.124024 & 3.197664 & Accepted \\
\hline $\begin{array}{l}\text { Leadership Style } \rightarrow \text { Nurse } \\
\text { Performance }\end{array}$ & 0.006336 & 0.070536 & 0.070536 & 0.089827 & Rejected \\
\hline $\begin{array}{l}\text { Leadership } \quad \text { Style } \\
\text { Organizational commitment }\end{array}$ & 0.080662 & 0.089908 & 0.089908 & 0.897155 & Rejected \\
\hline $\begin{array}{l}\text { Organizational commitment } \rightarrow \\
\text { Nurse performance }\end{array}$ & 0.396587 & 0.124024 & 0.124024 & 3.197664 & Accepted \\
\hline
\end{tabular}

Source: PLS Series 2, 2018 
Table 3. Hypothesis Testing Results Without The Role of Organizational Commitment

\begin{tabular}{|c|c|c|c|c|c|}
\hline $\begin{array}{c}\text { Relationship between } \\
\text { varables }\end{array}$ & $\begin{array}{c}\text { Original } \\
\text { Sample }\end{array}$ & $\begin{array}{c}\text { Standard } \\
\text { Deviation }\end{array}$ & $\begin{array}{c}\text { Standard } \\
\text { Error }\end{array}$ & $\begin{array}{c}\mathbf{t} \\
\text { Statistics }\end{array}$ & Results \\
\hline $\begin{array}{c}\text { Teamwork } \rightarrow \text { Nurse } \\
\text { Performance }\end{array}$ & 0.305186 & 0.113560 & 0.113560 & 2.687453 & $\begin{array}{c}\text { Significant } \\
\text { effect }\end{array}$ \\
\hline $\begin{array}{c}\text { Organizational Culture } \\
\rightarrow \text { Nurse Performance }\end{array}$ & 0.477519 & 0.106161 & 0.106161 & 4.498077 & $\begin{array}{c}\text { Significant } \\
\text { effect }\end{array}$ \\
\hline $\begin{array}{c}\text { Leadership Style } \rightarrow \\
\text { Nurse Performance }\end{array}$ & 0.038753 & 0.079281 & 0.079281 & 0.488803 & $\begin{array}{c}\text { Not } \\
\text { Significant }\end{array}$ \\
\hline
\end{tabular}

as a Mediation variable

Source: PLS Series 2, 2018

Picture 1. Bootstrapping Without Mediation Variables

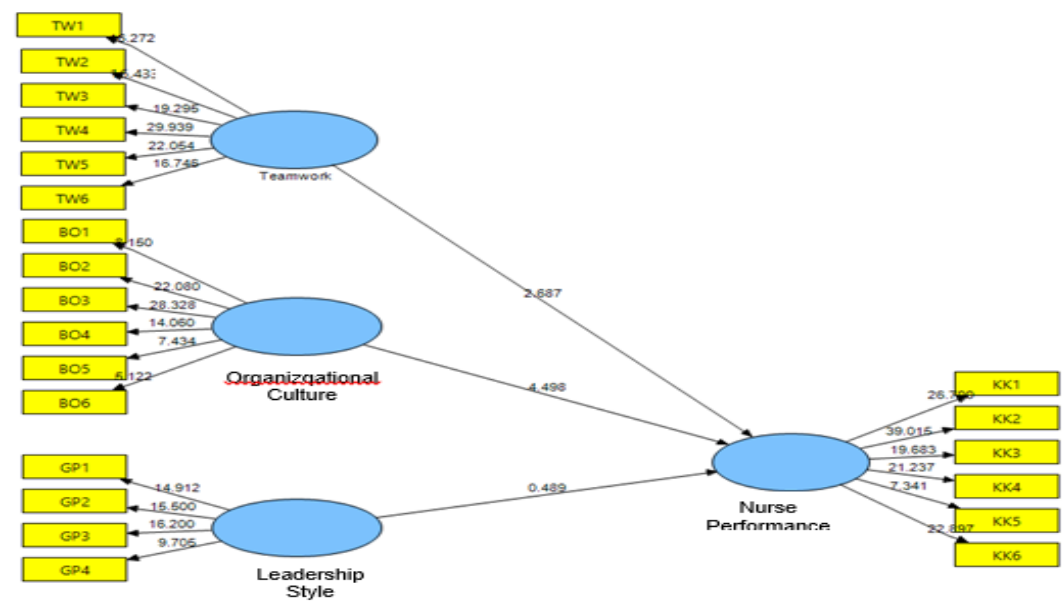


Source: PLS Series 2, 2018

Seeing the significance of the hypothesis by looking at the value of the parameter coefficient and t-statistical significance value on the algorithm boostrapping report. To find out significant or not significant seen from ttable at alpha $0.05(5 \%)=1.96$, then t-table compared by t-count $(\mathrm{t}-$ statistics). If the t-statistic is greater than t-table at alpha 0.05, the hypothesis is accepted, and vice versa. For more details, shown in Figure 2.

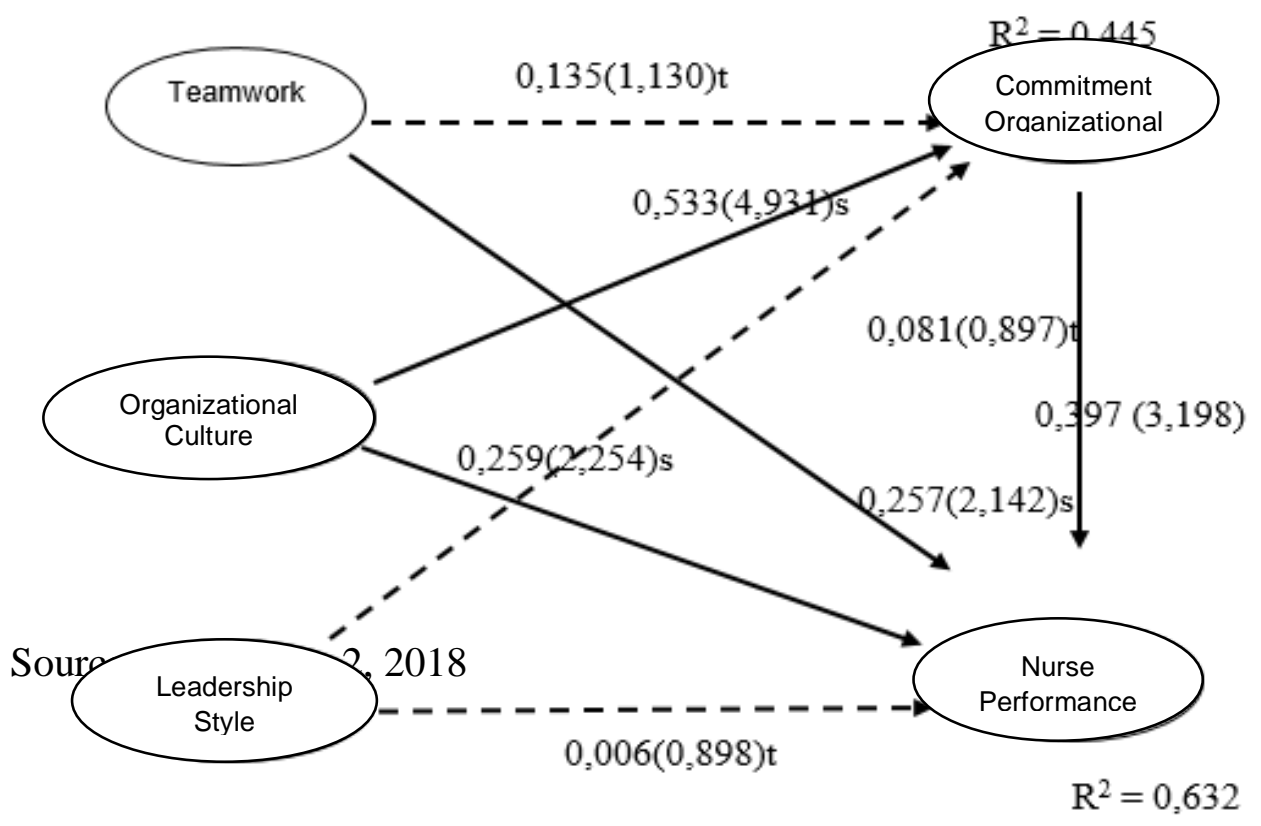

Figure 2. Hypothesis Testing Results

Vol. 27, No. 3 December 2019

(C) Centre for Indonesian Accounting and Management Research

Postgraduate Program, Brawijaya University 
In analyzing the influence of mediating variables, this study uses the approach taken by Baron and Kenny (1986). Both states that the position of the mediating variable in the model can act as a complete mediation variable, partial mediation, and / or not a mediating variable.

\section{Discussion}

\section{The Effect of Teamwork on Nurse Performance}

The results of the study found that teamwork had a positive effect on nurse performance. These results are in accordance with hypothesis 1 which is formulated, meaning that if nurses work in solid teamwork, it will be a factor that drives the success or improvement of nurse performance. When analyzed using a loading factor, the measuring teamwork indicator of encouragement ability (TW4) is the most dominant measure in measuring teamwork, where the average respondent's answer above 4.3 is classified as very good so that the nurse's performance can be increased. This is supported mainly by increasing the quantity of work indicators (KK2) as the most dominant indicator in reflecting nurse performance.

This research is not in line with Chen (2004) 's research which found that teamwork did not affect employee performance, but this study is in line with the research of Singer et al. (2009a), Brandrud et al. (2011), Paine et al. (2010), and Thomas (2011), that the establishment of a solid work team is very important as a factor that influences the increasing performance of an employee.

\section{The Effect of Teamwork on Organizational Commitment}

The results of the study found that teamwork did not affect organizational commitment. These results indicate that $\mathrm{H} 2$ is not accepted. This means that the teamwork that is built is not a factor that can influence the increased organizational commitment to the organization.

The results of this study are in harmony with the research of Pinho (2013), Che (2004), Wright (1997), and Rad and Yarmohammadian 
(2006), who found that teamwork did not affect organizational commitment. However, the results of this study are not in line with Costa's (2003) study, Chen, et al. (2009), Brown (2003), Preston and Brown (2004), and Lok and Crawford (2001), who found that teamwork had no effect on organizational commitment.Effect of Organizational Culture on Nurse Performance The results of this study found that organizational culture has a positive effect on nurse performance. . Discipline is an unavoidable provision, nurses have obeyed. The organizational culture in the hospital in the study was very good, only 0.01 that was not good needed the leadership attention to improve nurse performance. The results of this study support the research of Shein and Einar (2005), Parry and Thomson (2003), Azari (2015), Torvald et al. (2005), Goodman et al. (2001), Ebtesbam et al. (2011), who found that organizational culture had a positive effect on nurse performance. However, these results do not support the research of Raka (2003), and Brewer and Clippart (2002), who find that organizational culture does not affect nurse performance.

\section{The Effect of Organizational Culture on Organizational Commitment}

The results of the study found that organizational culture has a positive effect on organizational commitment. These results prove that $\mathrm{H} 4$ is accepted, meaning that the organizational culture that has been routinely carried out in hospital organizations is able to encourage increased organizational commitment to the organization. The results of this study support Chen's (2004) study, Rashid et al. (2003), and Rahmani et al. (2017) who found that organizational culture has a positive effect on organizational commitment. However, these results do not support Lok and Crawford's (2001) study, which found that organizational culture does not affect organizational commitment.

\section{The Effect of Leadership Style on Nurse Performance}

The results of the study found that leadership style did not affect nurse performance. This can be interpreted that the leadership style applied in hospitals does not have an impact on changing nurses' performance for the better.The results of this study do not support the study of de Groot et al. (2000), Silvethone and Wang (2001) and Robbins (2001) who found 
that leadership style had a positive effect on employee performance. However, the results of this study support the results of research by Ying and Ahmad (2008) who founded that leadership styles influence employee performance.

\section{The Effect of Leadership Style on Organizational Commitment}

Leadership style does not affect organizational commitment, that leadership style influences organizational commitment. However, nurses need appreciation for their hard work in handling patients, increasing needs for life, long-term work and low salaries, making urses' performance decline. The results of this study do not support the study of Zani and Hauser (2006), Avolio et al. (2004), Yousef (2000) and Lok and Croford (2004) who found that leadership styles had a positive effect on nurse commitment. However, the results of this study support the results of the Drury (2004) study which found that leadership style The results of this study support the research of Fang et al. (2004) who found that organizational commitment has a positive effect on employee performance. However, the results of this study do not support the results of research by Ying and Ahmad (2008), or Pinho (2013) who found that organizational commitment did not affect employee performance.

\section{The Role of Organizational Commitment in mediating the influence of Teamwork on Nurse Performance}

This study found that teamwork directly affects organizational commitment, however teamwork does not affect organizational commitment, while organizational commitment has a positive effect on nurse performance. This means that organizational commitment is not able to mediate the influence of teamwork on nurse performance. The results of this study do not support the Zincirkiran, Emhan and Yasar (2015) research which found that in the health sector in Turkey, organizational commitment was able to mediate the influence of teamwork on employee performance. The existence of solid teamwork has an impact on improving employee performance because employees have a high commitment to the organization. 


\section{The Role of Organizational Commitment in mediating the influence} of Organizational Culture on Nurse Performance. Organizational culture directly influences the performance of nurses smaller than the effect if without going through organizational commitment, then organizational commitment is able to mediate the influence of organizational culture on nurse performance in full (full mediating). This means that organizational culture not only has a direct effect on nurse performance, but moreover, it also has an indirect influence through organizational commitment. The results of this study support the Nikpour (2017) and Judge (2015) study, which found that organizational culture not only has a direct positive impact on organizational performance, but also indirectly influences organizational performance using employee organizational commitment and indirect impacts more than the direct impact.

\section{The Role of organizational commitment in mediating the influence of leadership style on nurse performance.} The results of this study found that organizational commitment was not able to play a role in mediating the influence of leadership style on nurse performance. Leadership style also did not influence nurse performance. However, organizational commitment is able to encourage increased nurse performance, especially the ability to work quantity.

\section{RESEARCH IMPLICATIONS}

\section{Theoretical implications}

The findings of this study can provide benefits in the development of theories in the field of human

resources.

1. The findings of this study are related to the variables forming indicators of organizational culture. From the theory put forward by Mullins (1999), stated that the variable of organizational culture is formed by six indicators, namely discipline, openness, initiative, risk development, communication, and altruistic innovation. The results of the study indicate that there are only five indicators forming variable organizational culture for nurses in several homes. Type B private

Vol. 27, No. 3 December 2019

(C) Centre for Indonesian Accounting and Management Research

Postgraduate Program, Brawijaya University 
hospital in DKI Jakarta, such as discipline, openness, initiative, risk development innovation, and altruistic. Communication indicators are apparently not variable indicators of organizational culture.

2. The findings of this study are also related to indicators forming leadership style variables. From the measurement of leadership style developed by Rivai (2004), that leadership style variable is formed by five indicators, namely participatory style, caregiver style, communication, knowing staff needs, and building trust. The results of the study found that only four indicators formed the leadership style variable for nurses in several type B private hospitals in DKI Jakarta, namely participatory style, caregiver style, communication, knowing staff needs. Indicators of building trust are not indicators of leadership style indicators.

3. The findings of this study are also related to the forming indicators of organizational commitment variables. From the measurement of organizational commitment developed by Mowday, et al. (1982), and Hackett, et al. (2001), that organizational commitment variables are formed by nine indicators, namely loyalty, involvement, working beyond the target, boasting the organization to others, accepting all tasks, being proud to be members of the organization, inspiring organizations, working in organizations, and caring for fate organization. The results of the study found that only seven indicators formed the organizational commitment variable for nurses in several type B private hospitals in DKI Jakarta, namely loyalty, involvement, working beyond the target, boasting oorganization to others, accepting all tasks, being proud to be members of the organization, and the organization inspires. Indicators like to work for organizations, and care about the fate of organizations is not an indicator forming indicators of organizational commitment.

\section{Practical / Managerial Implications for Organizations}

1. Teamwork turned out to have a positive effect on nurse performance. This shows that nurses at work already have the ability to give encouragement to fellow coworkers, thus encouraging their performance to increase. Management needs to further enhance the ability to consolidate their teamwork. 
2. Organizational culture also has a positive effect on nurse performance. Discipline culture has become the main thing that is attached to the implementation of the daily work of the nurses so that the impact on nurse performance is getting better. Discipline can have an impact on malpractice or the lives of patients as victims. For that the discipline of nurses must still be improved.

3. Organizational culture also has a positive effect on organizational commitment. Discipline culture is very attached to the daily work of nurses. This discipline will have an impact on the organization's commitment to work beyond the targets set by hospital management.

4. Organizational commitment turned out to also have a positive effect on nurse performance. The commitment of the nurses to work beyond the target determined by management to increase the quantity of work that can be done by nurses.

5. Organizational commitment was able to play a role in mediating the influence of organizational culture on nurse performance. Discipline culture that is inherent in the daily lives of nurses is able to increase the quantity of work that can be done by nurses is higher if the nurses have a commitment to work beyond the target.

\section{RESEARCH LIMITATIONS}

Not all hospitals give permission to conduct research, because of the limited human resources owned by the hospital.

\section{CONCLUSIONS AND SUGGESTIONS}

\section{Conclusion}

Based on the results of the research described in the previous chapter, the conclusions are as follows:

1. Teamwork has a positive effect on nurse performance. The implementation of nurses working in solid teamwork, especially in the ability to provide encouragement, can improve the performance of nurses, especially in the quantity of nurses' work.

2. Teamwork does not affect organizational commitment. The implementation of nurses who work in solid teamwork, especially in the ability to provide encouragement, is unable to increase 
organizational commitment, even in the commitment to work beyond the target.

3. Organizational culture has a positive effect on nurse performance. Implementation of the implementation of organizational culture adopted by all nurses, especially in disciplines, is able to improve nurse performance, especially in the quantity of nurses' work.

4. Organizational culture has a positive effect on organizational commitment. Implementation of the implementation of organizational culture adopted by all nurses, especially in discipline is able to increase organizational commitment, especially in the commitment to work beyond the target.

5. Leadership style does not affect the performance of nurses. The implementation of the leadership style, especially the participatory style and leadership communication that has been applied is not able to improve the performance of nurses, even in the increasing quantity of work.

6. Leadership style does not affect organizational commitment. The implementation of the leadership style, especially the participatory style and leadership communication that has been implemented is not able to increase organizational commitment, even on the commitment to work beyond the target.

7. Organizational commitment has a positive effect on nurse performance. Implementation of organizational commitment, especially in the commitment to work beyond the target is not able to improve performance, even in the increasing quantity of work.

8. Organizational commitment cannot play a role in mediating the influence of teamwork on nurse performance. The implementation of nurses who work in solid teamwork, especially in the ability to provide encouragement, is unable to increase organizational commitment, even in the commitment to work beyond the target. Implementation of organizational commitment, especially in the commitment to work beyond the target is not able to improve performance, even in the increasing quantity of work.

9. Organizational commitment is able to play a role in mediating the influence of organizational culture on nurse performance. Implementation of the implementation of organizational culture 
adopted by all nurses, especially in discipline is able to increase organizational commitment, especially in the commitment to work beyond the target. Implementation of organizational commitment, especially in the commitment to work beyond the target is not able to improve performance, even in the increasing quantity of work.

10. Organizational commitment cannot play a role in mediating the influence of leadership style on nurse performance. The implementation of the leadership style, especially the participatory style and leadership communication that has been implemented is not able to increase organizational commitment, even on the commitment to work beyond the target. Implementation of organizational commitment, especially in the commitment to work beyond the target is not able to improve performance, even in the increasing quantity of work.

Suggestion

1. Need a policy to increase the ability to provide encouragement to fellow nurses by conducting

regular training.

2. Improve discipline culture by giving performance points to get awards at the end of the year.

3. Increasing the commitment of nurses to work beyond the target by adjusting income with excess work hours.

4. Increasing the ability to complete the quantity of work by giving direction by nurse nurses.

\section{REFERENCE}

Abdel Aziz, H.H. and Rizkallah, A. (2015). Effect of organizational factors on employees' generation of innovative ideas. EuroMed Journal of Business, Vol.10 (2), p.134-146.

Ahmad, N. and N. O. Oranye. (2010). Empowerment, job satisfaction and organizational commitment: a comparative analysis of nures working in Malaysia and England. J Nurs Manag, Vol.18 (5), p.582-591.

Ahmad. (2012). Corporate leadeRumah Sakithip and workplace motivation in alaysia", International Journal of Commerce dan Management, Vol.11 No.1, p.82-101 
Al-Sada, M., Al-Esmael, B., \& Faisal, M. N. (2017). Influence of organizational culture and leadership style on employee satisfaction, commitment and motivation in the educational sector in Qatar. EuroMed Journal of Business, Vol.12 (2), p.163-188.

Ament, S. M.C., Gillissen, F., Maessen, J. M. C., Dirksen, C. D., van der Weijden, T., dan von Meyenfeldt, M. F. (2012). Sustainability of healthcare innovation (SUSHI): long term effects of two implemented surgical care programmes (protocol).

Andaleeb, S. S., Siddiqui, N, dan Khandakar, S. (2007). Doctor service orientation in public, private, and foreign hospitals. International Journal of Health Care, Vol.20 (3), p.253-263.

Antonakis, J., Fenley, M., dan Liechti, S. (2011). Can charisma can be taught? Tests of two interventions. The Academy of Management Learning and Education, Vol.10, p.374-396.

Arif Kamisan, R, dan King, B. E. M. (2013). Transactional and transformational leadership: A comparative study of the difference between Tony Fernandes (Airasia) and Idris Jala (Malaysia Airlines) leadership styles from 2005-2009. International Journal of Business and Management, Vol.8, p.107-116. http://doi.org/vq

Armanu Thoyib. (2005). Hubungan Kepemimpinan, Budaya, Strategi dan Kinerja: Pendekatan Konsep,Jurnal Manajemen dan Kewirausahaan, Vol.7, No. 1, Maret 2005, h. 60- 73 assessing transformational and transactional leadership. Journal of Applied Psychology, Vol.88 (2), p.207-218. Behavior, Institutions, and Organizations Across Nations, Sage.

Bass, B. M., dan Riggio, R. E. (2006). Transformational leadership. Mahwah: Erlbaum.

Berwick, D. M. 2008. The triple aim: Care, health and cost. Health Affair, Vol.27 (3), p.759-769. http://doi.dx.org/10.1377/hlthaff.27.3.759

Brandrud, A.S., Schreimer, A. Hjortdahl, P. Helljesen, G.S. Bjørnar, N. and Nelson, E.C. (2011). Three success factor for continual improvement in healthcare: an analysis of the reports of improvement team members. Quality and Safety in Health Care, Vol.20, No.3, p.251-259.

Camilleri E. (2006). Towards developing an organizational commitment - public service motivation model for the Maltese public service employees. Public. Policy. Adm., Vol.21 (1), p.63-83.

Vol. 27, No. 3 December 2019

(C) Centre for Indonesian Accounting and Management Research Postgraduate Program, Brawijaya University 
Carter, M. Z., Anmenakis, A. A., Feild, H. S., dan Mossholder, K. W. (2013). Transformational leadeship, relationship quality, and employee performance during continuous incremental organizational change. Journal of Organizational Behavior, Vol.34, p.942-958. http://doi.org/vq7.

Chan R. K. H. dan Wang Y. (2013). The quest for legitimacy in a traditional economy: a comparison of private hospitals in China and Vietnam. Journal of Comparative Asian Development, Vol.12 (1), p.60-83. Change in large organizations. London: Sage.

Coetzee, Melinde. (2005). The relationship between pesprsonality preferences, selfesteem and emotional competence. The Journal of American Academy of Business, p.432-438. comparate culture: a field test of the value congruence process and its relationship to individual outcomes. Journal of applied psychology. 7 Comparison", The Journal of Management Development, Vol.23.

Daft, R. (2005). The leadership experience. Ohio: Thomson SouthWestern.

Daft, L. Richard. (2012). New Era of Management. International Edition, South -Western, Cengange Learning. Data Analysis With Readings, Englewood Cliffs, NJ: Prentice Hall.

Davies, H.T.O., Mannion, R., Jacobs, R., Powell, A.E. and Marshall, M.N. (2007). Exploring the relationship between senior management team culture and hospital performance. Medical Care Research and Review, Vol.64 No.1, p. 46-65.

Diab, S. M., dan Ajlouni, M. T. (2015). The influence of training on employee's performance, organizational commitment, and quality of medical services at Jordanian private hospitals. International Journal of Business and Management, Vol.10 (2), p.117-127.

Ebstebarm Mujeeb, UI., Tahir Masood dan haki Ahmad Muhammad. (2011). Relationship between Organzational Culture nd Performance Management Practices; A Case of University in Pakistan, Journal of Competitiveness, Vol.4 (18), p.06-48.

Gallie, D., Zhou, Y. Felstead, A., dan Green, F. (2009). Teamwork, productive potential, and employee welfare. Skope Research Paper, Vol.84, p.1-28.

Gephart, R. P. (2004). From the editor: Qualitative research and the Academy of Management Journal. Academy of Management Journal, Vol.47 (4), p.454-462. 
Gephart, R. P. dan Richardson, J. (2008). Qualitative research methodologies and international human resource management. In M. Harris (Ed.), Handbook of research in international human resources (p. 29-52).

Ghozali, Imam. (2013). Aplikasi Analisis Multivariate Dengan Program SPSS, cetakan IV. Semarang: Badan Penerbit Univesitas Diponegoro.

Gibson, James L et al. (2006). Organizations (Behavior, Structure, Processes). Twelfth Edition, McGrow Hill.

Gill, R. (2006). Theory and practice of leadership. London: Sage Publications.

Gilmore, Hu, Wei, Tetrick, dan Zaccaro. (2013). Positive affectivity neutralizes transformational leadership's influence on creative performance and organizational citizenship behavior. Journal of Organizational Behavior, Vol.34, p.1061-1075. http://doi.org/vq8.

Gurtner, A., Tschan, F., Semmer, N. K., danNägele, C. (2007). Getting groups to develop good strategies: Effects of reflexivity interventions on team process, team performance, and shared mental models. Organizational Behavior and Human Decision Processes, Vol.102, p.127-142.

Hair J.F., Anderson, R.L., Black, W.G., Babin, B.J. (2014). Multivariate Data Analysis, Pearson Education Limited, Essec.

Hair, J.F., Hult, G.T.M., Ringle, C.M., and Sarstedt, M. (2017). A Primer on Partial Least Squares Structural Equation Modeling (PLS-SEM). SAGE Publications, Inc. California.

Hanaysha, Jalal. (2016). Examining the Effects of Employee Empowerment, Teamwork, and Employee Training on Organizational Commitment. 5th International Conference on Leadership, Technology, Innovation and Business Management.

Hausknecht, J. P., Rodda, J., dan Howard, M. J. (2009). Targeted employee retention: Performance-based and job-related differencies in reported reasons for staying. Human Resource Management, Vol.48, p.269-288.

Hojjat, Rahmani. (2015). Organizational Culture and the Organizational Commitment Correlational Study in Hospital Staffs. Asian Social Science, Vol.11, No.5. 
Jason A. Colquitt, Jeffery A Le Pine, and MichaelJ. Wesson. (2014). Organizational Behavior.Fourth Edition. Journal of American Academy of Business, Sep 2004, 5, 1/2, p.432-438.

Jose' Carlos Pinho. (2013). School of Economics and Management, University of Minho, Braga, Portugal.

Kennedy, R. (2008). How do we get the manager we need and the leadership we want? A personal view. Journal of Nursing Management, Vol.16, p.942-945.

Khan, V. H., Hafeez, M. H., Rizvi, S. M. H., Hasnain, A., dan Marian, A. (2012). Relationship of leadership styles, employees commitment and organization performance. European Journal of Economics, Finance and Administration.

Khyzer and Ahmed. (2011). Impact of employee commitment on organizational performance. Arabian journal of Business and Management Review, Vol.1 (3), p.87-98.

Kocel, T. (2011). Isletme Yoneticiligi Business management] (3rd ed.). Istanbul: Beta Basim.

Kumar, C. R., dan Kaptan, S. S. (2007). The leadership in management: Understanding leadership wisdom. New Delhi: APH Publishing.

Lantu, D., Pesiwarissa, E., dan Rumahorbo, A. (2007). Servant Leadership. Yogyakarta: Gradien Books.

Lee H. dan Cummings G. (2008). Factor influencing job satisfaction of front line manager Sakit: A systematic review. Journal of Nursing Management, Vol.16, p.768-783.

Lee Huey Yiing and Kamarul Zaman Bin Ahmad. (2008). Faculty of Business and Accountancy

Leiter, M. P., Jackson, N. J., dan Shaughnessy, K. (2009). Contrasting burnout, turnover intention, control, value congruence and knowledge sharing between Baby Boomers and Generation X. Journal of Nursing Management, Vol.17 (1), p.100-109.

Luthans, Fred, (2006), Perilaku Organisasi, Edisi Sepuluh, Managerial Application", The Free Press, New York, NY, p. 11-18.

Mahwah, NJ: Lawrence Earlbaum Associates. Goleman, D. (2007). Sosyal zekâ, insan ilişkilerinin yeni bilimi, İstanbul: Varlık Yayınları.

Martin, G. P., Weaver, S., Currie, G., Finn, R., dan McDonald (2012). Innovation sustainability in challenging health-care contexts: 
embedding clinically led change in routine practice. Health Services Management Research, Vol.25, p.190-199.

Mathieu, J. Maynard, M.T.,Rapp, T. and Gilson, L. (2008). Team effectiveness 1997-2007: a review of recent advancements and a glimpse into the future. Journal of Management, Vol.34, No.3, p.410-476.

McClure, R.E. (2010). The influence of organizational culture and conflict on market orientation. Journal of Business and Industrial Marketing, Vol.25, No.7, p.514-524.

Murwaningsari, E. (2008). The Role Of Organizational Commitment dan Procedural Justice In Moderating The Relationship Between Budgetary Participation dan Managerial Performance. Gadjah Mada International Journal of Business, Vol.10, p.185-210.

Neuza Ribeiro, Daniel Gomes, Shaji Kurian. (2018). Authentic leadership and performance: the mediating role of employees'affective commitment. Social Responsibility Journal, Vol.14 (1), p.213-225.

Northouse, P. G. (2007). Leadership Theory and Practice. London: Sage Publications

Ojo, O. (2009). Impact assesment of Corporate Culture On employee Job Performance. Journal Business Intelligence, Vol.2 (2), p.388-397.

Paine, L.A., Rosenstein, B.J., Sexton, J.B., Kent, P., Holzmueller, C.G. and Pronovost, P.J. (2010). A prospective cohort study. Quality and Safety in Health Care, Vol.19, No.6, p. 547-554.

Reiche, B. S. (2008). The configuration of employee retention practices in multinational corporations foreign subsidiaries. International Business Review, Vol.17, p.676-687.

Ribeiro, N., Gomes, D., \& Kurian, S. (2018). Authentic leadership and performance: the mediating role of employees' affective commitment. Social Responsibility Journal, Vol.14 (1), p.213225.

Robbins S.P. and Judge, T.A. (2015). Organizational Behavior, 16th ed. Pearson Education, Inc. New Jersey.

Rusliza Yahaya, Fawzy Ebrahim, (2016) Leadership styles and organizational commitment: literaturereview. Journal of Management Development, Vol.35 (2), p.190-216,

Salas, E., Cooke, N.J. and Rosen, M.A. (2008). On teams, teamwork, and team performance: discoveries and developments", Human Factor.

Vol. 27, No. 3 December 2019

(C) Centre for Indonesian Accounting and Management Research Postgraduate Program, Brawijaya University 
The Journal of the Human Factors and Ergonomics Society, Vol.50, No.3, p.540-547.

Sargeant, J., Loney, E., dan Murphy, G. (2008). Effective interprofessional teams: "Contact is not enough" to build a team. Journal of Continuing Education in the Health Professions, Vol. 28 (4), p.228-234.

Schein, E., H. (2014). Organizational Culture and Leadership, 4th ed. John Wiley dan Sons.

Shu-Mei Tseng. (2009). The correlation between organizational culture and knowledge conversation on corporate performance. I-Shou University, Dashu Township, Taiwan, Republic of China.

Singer, S.J., Falwell, A., Gaba, D.M., Meterko, M., Rosen, A., Hartmann, C.W. and Baker, L. (2009a). Identifying organizational cultures that promote patient safety. Healthcare Management Review, Vol.34, No.4, p.300-311.

Solimun. (2012). Pemodelan Generalized Structured Component Analysis (GeSCA). Program Studi Statistika FMIPA, PDIM FE Universas Brawijaya.

Tennant, S., Langford, D. (2006). Team performance measurement: Let's reward teamwork. 22nd Annual ARCOM Conference, p.189-197.

Thomas, E.J. (2011). Improving teamwork in healthcare: current approaches and the path forward. Quality and Safety in Health Care, Vol.20 No.8, p. 647-650.

Tser-Yieth Chen, S. H. Y. L. (2009). Employee Trust, Commitment, and Satisfaction as Moderator of the Effects of Idealized dan Consideration LeadeRumah Sakithip on Voluntary Performance:

A structural Equation Investigation. International Journal of Management, Vol.26, p.127-141

Unger, J. M., Rauch, A., Frese, M., dan Rosenbusch, N. (2011). Human capital and entrepreneurial success: a meta-analytical review. Journal of Business Venturing, Vol.26, p.341-358.

Yiing, L. and Ahmad, Z. (2009). The moderating effects of organizational culture on the relationships between leadership behaviour and organizational commitment and between organizational commitment and job satisfaction and performance, Leadership dan Organization Development Journal, Vol. 30 No. 1, p.53-86. 
Yilmaz C. Ergun E. (2008). Organizational Culture and Firm Effectiveness: An Examination of Relative Effects of Culture Traits and the Balanced Culture Hypothesis in an Emerging Economy, J. of World Business, 43, p.290-30.

Zagoesek, H., Dimovski, V. dan Skerlavaj, M. (2009). Transactional and transformational leadership impacts on organizational learning. Journal for East European Management Studies, 14, p.144-165.

Zehira Cemal, Yasin Sehitoglub, Ebru Erdogana. (2012). The Effect of Leadership and Supervisory Commitment to Organizational Performance.

Zhenpeng Luo, Einar Marnburg, Rob Law. (2017). Linking leadership and justice to organizational commitment: The mediating role of collective identity in the hotel industry, International Journalof Contemporary Hospitality Management, Vol. 29 Issue: 4, p. 11671184. 
136 The Effect of Team Work,Leadership Style, and Organizational Culture.....

Vol. 27, No. 3 December 2019

(C) Centre for Indonesian Accounting and Management Research Postgraduate Program, Brawijaya University 